\title{
UPAYA MENCEGAH PENYEBARAN DAN PENULARAN VIRUS COVID 19 DI LINGKUNGAN KERJA MASYARAKAT DESA LUBUK KETEPENG KECAMATAN JEJAWI PADA MASA PANDEMI COVID 19
}

\author{
Mujahidin \\ Dosen Program Studi Ilmu Keperawatan STIK Bina Husada Palembang \\ Jl. Syech Abdul Somad No 28 Kelurahan 22 Ilir Palembang 30131 \\ mujahidinners@yahoo.com
}

\begin{abstract}
Abstrak
Latar Belakang: Desember 2019 lalu dunia dikejutkan dengan mewabahnya coronavirus disease atau SARS-CoV2 atau banyak orang yang menyebutnya dengan virus covid 19 yang pertama kali terdeteksi di kota Wuhan Provinsi Hubei Cina dan sampai saat ini sudah menjadi pandemic di seluruh dunia. Tujuan. Mengetahui upaya yang dilakukan warga Desa Lubuk Ketepeng Kecamatan Jejawi Kabupaten Ogan Komering Ilir di lingkungan kerja dalam upaya mencegah penularan dan penyebaran virus covid 19 masa pandemi. Metode. Penelitian ini merupakan peneletian survey deskriptif. Sampel dalam penelitian ini adalah warga Desa Lubuk Ketepeng berjumlah 40 orang yang dipilih dengan menggunakan tehnik simple random sampling serta memenuhi kriteria. Hasil: Hasil penelitian didapatkan informasi informasi tentang upaya yang dilakukan warga Desa Lubuk Ketepeng di lingkungan kerja untuk mencegah penyebaran dan penularan virus covid 19 pada masa pandemi. Simpulan. Upaya yang dilakukan oleh warga sudah benar dan mengikuti protokol kesehatan yang telah dihimbau oleh pemerintah, peningkatan kedisiplinan dalam menerapkan protocol kesehatan ketika berada di lingkungan kerja ini akan berkontribusi besar dalam upaya mencegah dan memutus mata rantai penularan virus covid 19.
\end{abstract}

\section{Kata Kunci : Pola Prilaku Warga, Virus Covid 19}

\begin{abstract}
Background: December 2019 last year the world was shocked by the outbreak of coronavirus disease or SARS-CoV2 or many people call it covid virus 19 which was first detected in the city of Wuhan Hubei Province of China and has so far become a worldwide pandemic. Destination. Knowing the efforts made by the residents of Lubuk Ketepeng Village, Jejawi District, Ogan Komering Ilir Regency in the work environment in an effort to prevent the spread and spread of covid virus 19 during the pandemic. Method. This study is a descriptive survey study. The sample in this study is the residents of Lubuk Ketepeng Village, a total of 40 people were selected using simple random sampling techniques and meet the criteria. Results: The results of the study obtained information about the efforts made by the residents of Lubuk Ketepeng Village in the work environment to prevent the spread and transmission of covid virus 19 during the pandemic. Conclusion. Efforts made by citizens are correct and follow the health protocol that has been called for by the government, increasing discipline in implementing health protocols while in this work environment will contribute greatly to efforts to prevent and break the chain of transmission of covid virus 19.
\end{abstract}

Keywords: Citizen Behavior Patterns, Covid Virus 19 


\section{PENDAHULUAN}

\subsection{Latar Belakang}

Virus covid 19 atau coronavirus disease atau SARS-

CoV-2 sudah sejak beberapa bulan terahir ini mewabah dan menjadi pandemi hampir diseluruh penjuru dunia sejak kemunculannya pertama kali di kota Wuhan Provinsi Hubei Cina pada ahir tahun atau tepatnya di bulan desember 2019 lalu. Saat ini angka kasus covid 19 menurut data WHO per tanggal 31 Oktober 2020 diseluruh dunia tercatat sudah lebih dari 44 juta dan diperkirakan masih akan terus meningkat.

Di Indonesia angka kasus positif yang terkonfirmasi sebanyak 400 ribu lebih. Sedangkan di Sumatera Selatan, sampai dengan saat ini 31 Oktober 2020 ini sudah terkonfirmasi sebanyak 7 kasus lebih.

Melihat angka kasus baru yang terus meningkat, hal ini tentu menimbulkan banyak sekali dampak terhadap sendi sendi kehidupan masyarakat. Dampak yang paling banyak dirasakan diantaranya adalah dampak ekonomi dan dampak kesehatan. Pada dampai ekonomi ada banyak masyarakat yang menerima pemutusan hubungan kerja, usaha yang macet dan situasi perekonomian local yang sedang lesu.

Untuk mengatasi situasi pandemic ini, tentu tidak bisa kita tidak bisa semata mata membebankan pada pemerintah saja, semua unsur harus bersatu padu mulai dari atas sampai ke bawah secara bersama sama dan bahu membahu memerangi pandemic covid 19 ini.

Beberapa upaya atau dukungan yang bisa kita lakukan untuk mendukung pemerintah dalam upaya mengentaskan permasalahan ini salah satunya adalah dengan mengikuti himbauan yang telah telah disampaikan oleh pemerintah. Menggunakan masker, mencuci tangan menggunakan sabun, menjaga jarak dengan orang lain adalah himbauan yang sudah disampaikan oleh pemerintah yang bisa kita lakukan dan sebenarnya akan memberikan dampak atau pengaruh besar dalam hal memutus mata rantai penularan apabila kita disiplin dalam mejalankannya.

\section{Metode Penelitian}

Penelitian ini merupakan penelitian survey deskriptif dimana dalam penelitian ini peneliti melakukan pengumpulan data data tentang upaya mencegah penyebaran dan penularan virus covid 19 di lingkungan kerja warga Desa Lubuk Ketepeng pada masa pandemi.

Populasi dalam penelitian ini adalah seluruh warga Desa Lubuk Ketepeng dan sample dalam penelitian ini adalah warga Desa Lubuk Ketepeng berjumlah 40 orang yang dipilih dengan menggunakan tehnik simple random sampling serta memenuhi kriteria yang telah ditentukan yaitu : Warga Desa Lubuk Ketepeng, jenis kelamin laki laki dan perempuan, usia $18-60$ tahun, dalam kondisi sehat dan bersedia berpartisipasi.

Pengumpulan data dalam penelitian ini dilakukan dengan menggunakan formulir instrument pengumpulan data yang selanjutnya formulir tersebut dibagikan ke sampel penelitian dengan menggunakan email, whatshap dan komunikasi secara langsung dengan menggunakan telepon. Setelah formulir diisi sampel mengirimkan kembali formulir tersebut ke email, 
whatshap peneliti. Seteleh 40 formulir yang telah diisi terkumpul dilakukan entry data ke dalam program SPSS dan selanjutnya disajikan dalam bentuk tabel distribusi frekuensi

\section{Etika Penelitian}

Sampel yang berpartisipasi terlebih dahulu diminta kesediaannya

Identitas sampel dirahasiakan

Proses pengumpulan data sepenuhnya tidak dilaksanakan dengan melakukan kontak langsung antara peneliti dengan sampel penelitian

Interaksi yang dilakukan dengan menggunakan email, whatshap, video conference

\section{Hasil}

\section{Karakteristik Sampel Penelitian}

\section{Umur Sampel Penelitian}

\begin{tabular}{ccc}
\hline Umur & Frekuensi & Persen \\
\hline 18 & 2 & 5.0 \\
20 & 1 & 2.5 \\
25 & 1 & 2.5 \\
27 & 3 & 7.5 \\
29 & 1 & 2.5 \\
30 & 1 & 2.5 \\
31 & 1 & 2.5 \\
33 & 2 & 5.0 \\
34 & 1 & 2.5 \\
35 & 4 & 10.0 \\
36 & 1 & 2.5 \\
37 & 2 & 5.0 \\
38 & 2 & 5.0 \\
39 & 1 & 2.5 \\
42 & 1 & 2.5 \\
43 & 2 & 5.0 \\
46 & 2 & 5.0 \\
48 & 2 & 5.0 \\
49 & 3 & 7.5 \\
50 & 2 & 5.0 \\
52 & 1 & 2.5 \\
58 & 2 & 5.0 \\
59 & 1 & 2.5
\end{tabular}

\begin{tabular}{ccc}
60 & 1 & 2.5 \\
\hline Total & $\mathbf{4 0}$ & $\mathbf{1 0 0 . 0}$ \\
\hline
\end{tabular}

\section{Jenis Kelamin Sampel Penelitian}

\begin{tabular}{lcc}
\hline Jenis Kelamin & Frekuensi & Persen \\
\hline Laki Laki & 31 & 77.5 \\
Perempuan & 9 & 22.5 \\
\hline Total & $\mathbf{4 0}$ & $\mathbf{1 0 0 . 0}$ \\
\hline
\end{tabular}

\section{Status Pernikahan}

\begin{tabular}{lcc}
\hline Status Pernikahan & Frekuensi & Persen \\
\hline Belum Menikah & 7 & 17.5 \\
Duda & 1 & 2.5 \\
Janda & 2 & 5.0 \\
Menikah & 30 & 75.0 \\
\hline Total & $\mathbf{4 0}$ & $\mathbf{1 0 0 . 0}$ \\
\hline
\end{tabular}

\section{Jumlah Anggota Keluarga}

\begin{tabular}{ccc}
\hline $\begin{array}{c}\text { Jumlah Anggota } \\
\text { Keluarga }\end{array}$ & Frekuensi & Persen \\
\hline 1 & 2 & 5.0 \\
2 & 1 & 2.5 \\
3 & 7 & 17.5 \\
4 & 16 & 40.0 \\
5 & 10 & 25.0 \\
6 & 4 & 10.0 \\
\hline Total & $\mathbf{4 0}$ & $\mathbf{1 0 0 . 0}$ \\
\hline
\end{tabular}

\section{Status Pekerjaan}

\begin{tabular}{lcc}
\hline Status Pekerjaan & Frekuensi & Persen \\
\hline Ibu Rumah Tangga & 4 & 10.0 \\
Bekerja & 36 & 90.0 \\
\hline Total & $\mathbf{4 0}$ & $\mathbf{1 0 0 . 0}$ \\
\hline
\end{tabular}

\section{Tempat Bekerja}

\begin{tabular}{lcc}
\hline Tempat Bekerja & Frekuensi & Persen \\
\hline Kantor Instansi & 3 & 7.5 \\
Pemerintah & & \\
Pekerja Mandiri & 25 & 62.5 \\
Perusahaan & 6 & 15.0 \\
Rumah & 4 & 10.0 \\
Rumah Makan & 2 & 5.0 \\
\hline Total & $\mathbf{4 0}$ & $\mathbf{1 0 0 . 0}$ \\
\hline
\end{tabular}


Penggunaan masker atau alat pelindung diri di tempat kerja

\begin{tabular}{lcc}
\hline $\begin{array}{l}\text { Penggunaan } \\
\text { masker atau alat } \\
\text { pelindung diri di } \\
\text { tempat kerja }\end{array}$ & Frekuensi & Persen \\
\hline Kadang Kadang & 1 & \\
Memakai Masker & 35 & 87.5 \\
Tidak & 4 & 10.0 \\
Menggunakan & & \\
APD & & \\
\hline Total & $\mathbf{4 0}$ & $\mathbf{1 0 0 . 0}$ \\
\hline
\end{tabular}

Prosedur di tempat kerja untuk mencegah penyebaran dan penularan virus covid 19

\begin{tabular}{|c|c|c|}
\hline 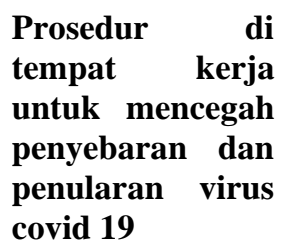 & Frekuensi & Persen \\
\hline Memakai & 32 & 80.0 \\
\hline $\begin{array}{l}\text { Memakai } \\
\text { Masker Cuci } \\
\text { Tangan Jaga } \\
\text { Jarak }\end{array}$ & 4 & 10.0 \\
\hline $\begin{array}{l}\text { Tidak } \\
\text { Menggunakan } \\
\text { APD }\end{array}$ & 4 & 10.0 \\
\hline Total & 40 & 100.0 \\
\hline
\end{tabular}

\section{Pembahasan}

Penelitian ini dilaksanakan pada bulan juni 2020 di Desa Lubuk Ketepeng Kecamatan jejawi Kabupaten Ogan Komering Ilir Provinsi Sumatera Selatan. Responden dalam penelitian ini berjumlah 40 orang yang dipilih dengan menggunakan tehnik simple random sampling serta memenuhi kriteria yang telah ditentukan. Pelaksanaan penelitian berpedoman pada protokol kesehatan covid 19 yang telah diinformasikan oleh Pemerintah sehingga pelaksaan penelitian tidak dilakukan dengan kontak langsung dengan responden. Pelaksanaan penelitian dilakukan dengan menggunakan media daring. Formulir pengumpulan data dibagikan ke responden dengan menggunakan whatshap, email dan komunikasi secara langsung dengan menggunakan saluran telepon.

Dari hasil penelitian terkumpul beberapa data data tentang karakteristik responden dan data tentang upaya yang dilakukan masyarakat Desa Lubuk Ketepeng di lingkungan kerja untuk mencegah penyebaran dan penularan virus covid 19 pada masa pandemi.

Umur responden yang paling banyak berpartisipasi dalam penelitian ini adalah umur 35 tahun sebanyak 4 orang responden (10\%), sedangkan sisanya adalah umur 49 sebanyak 3 orang responden $(7.5 \%)$, umur 27 sebanyak 3 orang responden (7.5\%), umur 58, 50,48, 46, 43, 38, 37,33 dan 18 sebanyak masing masing 2 orang responden $(5.0 \%)$ dan umur 60, 59, 52, 42, 39, 36, 34, $31,30,29,25$ dan umur 20 tahun sebanyak masing masing 1 orang responden $(2.5 \%)$. Dalam penelitian ini dilakukan pengklasifikasian umur yaitu umur 18 - 60 tahun.

Jenis kelamin responden yang berpartipasi dalam penelitian ini paling banyak adalah laki laki dengan 31 orang responden $(77.5 \%)$ dan sisanya adalah perempuan dengan 9 orang responden (22.5\%).

Dari status pernikahan 40 orang responden yang berpartisipasi sebanyak 30 responden dengan status sudah menikah (75.0\%), 7 orang responden $(17.5 \%)$ belum menikah, 2 orang responden $(5.0 \%$ janda dan 1 orang responden $(2.5 \%)$ dua.

Untuk status pekerjaan 40 orang responden yang berpartisipasi 
sebanyak 36 orang responden $(90.0 \%)$ bekerja dan 4 orang responden $(10.0 \%)$ sebagai ibu rumah tangga.

Jumlah anggota keluarga paling banyak yang memiliki 4 orang anggota keluarga sebanyak 16 orang responden (40.0\%), 5 orang anggota keluarga sebanyak 10 responden (25.0\%), 3 orang anggota keluarga sebanyak 7 responden (17.5\%), 6 orang anggota keluarga sebanyak 4 responden $(10.0 \%), 2$ orang anggota keluarga sebanyak 1 responden $(2.5 \%)$ dan 1 orang oanggota keluarga sebanyak 2 responden $(5.0 \%)$.

\section{Upaya yang dilakukan di lingkungan kerja untuk mencegah penyebaran dan penularan virus covid 19 pada masa pandemi.}

Seperti yang sudah dikemukakan diatas, bahwa dari 40 responden yang berpartisipasi sebanyak 36 orang responden $(90.0 \%)$ bekerja. Beberapa pekerjaan responden diantaranya adalah pekerja di kantor instansi pemerintahan, perusahaan swasta/PT, rumah makan, dan sisanya adalah pekerja mandiri seperti pedagang, petani, berkebun, berniaga. 4 orang responden $(10.0 \%)$ tidak bekerja karna merupakan ibu rumah tangga.

Data status pekerjaan ini ditelusuri oleh peneliti agar dapat mengetahui interaksi dan upaya yang dilakukan oleh sampel penelitian dalam kesehariannya di lingkungan kerja. Kondisi di lingkungan kerja sangat memungkinkan untuk bertemu dengan orang orang lain, berinteraksi, yang ini menjadi potensi untuk menyebaran dan penularan virus covid 19. Upaya yang dilakukan sampel penelitian ketika berada di tempat kerja yaitu menggunakan masker dilakukan oleh 35 orang responden $(87.5 \%), 1$ orang responden $(2.5 \%)$ kadang kadang dan 4 orang responden $(10.0 \%)$ tidak menggunakan alat pelindung diri karna tidak bekerja/bekerja di rumah sebagai ibu rumah tangga. Di tempat kerja upaya yang dilakukan untuk mencegah penyebaran dan penularan virus covid 19 adalah sebagian besar dengan menggunakan masker sebanyak 35 orang responden $(87.5 \%)$ membiasakan mencuci tangan dan menjaga jarak.

Di lingkungan kerja juga banyak terdapat alat alat atau benda yang sering kali bersifat umum dan bisa di pegang oleh siapa saja, seperti misalnya alat alat untuk bekerja dan sarana prasarana lain. Hal ini menimbulkan kekhawatiran akan transmisi virus dari benda ke orang melalui sentuhan terhadap benda tersebut, namun potensi penularan virus covid 19 melalui benda cukup rendah, dikarenakan virus ini akan mati apabila menempel pada suatu benda seperti alat alat untuk bekerja, bahan makanan sayur, buah, alat alat makan dan pakaian, karna untuk bisa hidup pada media tersebut virus ini membutuhkan inang. Namun terlepas dari kecilnya potensi itu tindakan pencegahan seperti mencuci hal hal itu dengan sabun adalah salah satu upaya yang bisa dilakukan dan akan memberikan berkontribusi dalam mencegah terjadinya penularan. Selain itu menjaga jarak, tidak berkumpul/berkerumun. Mencuci tangan sebelum memegang wajah, menutup mulut dan menghidarkan diri ketika batuk dan bersin juga akan berkontribusi besar dalam memutus penyebaran dan penularan virus covid 19 ini. 


\section{Simpulan dan Saran}

\subsection{Simpulan}

Dari hasil penelitian yang telah dilakukan dapat ditarik kesimpulan bahwa masyarakat Desa Lubuk Ketepeng dalam berprilaku untuk mencegah penyebaran dan penularan virus covid 19 di lingkungan kerja sudah dilaksanakan dengan baik dan mengikuti protokol yang telah dihimbau oleh pemerintah seperti misalnya menggunakan masker, menjaga jarak dan membiasakan mencuci tangan.

\subsection{Saran}

Perlunya disiplin dan komitmen bersama di segenap lapisan masyarakat untuk menjaga dan menerapkan protokol kesehatan dalam mencegah penyebaran dan penularaan virus covid 19 ini. Membiasakan mencuci tangan, mencuci bahan bahan makanan, alat alat makan dengan sabun, menutup mulut ketika batuk atau bersin, menghidar ketika ada orang yang batuk atau bersin, tidak memegang area muka sebelum mencuci tangan dengan sabun, menjaga jarak dan menggunakan pelindung diri seperti minimal menggunakan masker khususnya di lingkungan kerja adalah upaya berprilaku yang benar untuk kita bersama sama memutus dan mencegah penularan virus covid 19 ini.

\section{DAFTAR PUSTAKA}

Analisis prilaku masyarakat
$\begin{aligned} & \text { Indonesia } \\ & \text { dalam }\end{aligned}$
$\begin{aligned} & \text { menghadapi virus } \\ & \text { Diakses }\end{aligned}$

corona.sumsel.go.id.

Diakses Juni 2020

covid19.go.id

Diakses Juni 2020

Corona virus.

https://www.kemkes.go.id.

Diakses Juni 2020

Coronavirus desease 2019 :

Tinjauan literatur

jurnalpenyakitdalam.ui.ac.id

Diakses Juni 2020

Faktor faktor yang mempengaruhi tingkat prilaku hidup bersih

dan

sehat. ejournal.umm.ac.id.

Diakses Juni 2020

Faktor faktor psikologis yang mempengaruhi prilaku hidup sehat. respiratori.uinjkt.ac.id. Diakses Juni 2020

Kajian teori prilaku. etheses.uin-malang.ac.id. Diakses Juni 2020

Kebiasaan berprilaku hidup sehat. journal.uny.ac.id. Diakses Juni 2020

Konsep prilaku. repository.poltekkesdenpasar.ac.id .Diakses Juni 2020

Pengaruh prilaku individu terhadap hidup sehat. juke.kedokteran.unila.ac.id. Diakses Juni 2020

Studi tentang pembentukan kebiasaan

dan prilaku sosial siswa. jurnal.upmk.ac.id. Diakses Juni 2020

Studi eksplorasi prilaku hidup bersih dan sehat. pasca.um.ac.id. Diakses Juni 2020

Virus corona (2019 -nCoV jbiomedkes.org. Diakses Juni 2020

Juni 2020 